University of Nebraska - Lincoln

DigitalCommons@University of Nebraska - Lincoln

$3-2004$

\title{
Growth of Stocker Channel Catfish to Large Market Size in Single- Batch Culture
}

Bartholomew W. Green

bart.green@usda.gov

Carole R. Engle

University of Arkansas at Pine Bluff

Follow this and additional works at: https://digitalcommons.unl.edu/usdaarsfacpub

Part of the Agriculture Commons, and the Aquaculture and Fisheries Commons

Green, Bartholomew W. and Engle, Carole R., "Growth of Stocker Channel Catfish to Large Market Size in Single-Batch Culture" (2004). Publications from USDA-ARS / UNL Faculty. 2397.

https://digitalcommons.unl.edu/usdaarsfacpub/2397

This Article is brought to you for free and open access by the U.S. Department of Agriculture: Agricultural Research Service, Lincoln, Nebraska at DigitalCommons@University of Nebraska - Lincoln. It has been accepted for inclusion in Publications from USDA-ARS / UNL Faculty by an authorized administrator of DigitalCommons@University of Nebraska - Lincoln. 


\title{
Growth of Stocker Channel Catfish to Large Market Size in Single-Batch Culture
}

\author{
BARTHOLOMEW W. GREEN \\ USDA-ARS Aquaculture Systems Research Unit. Aquaculture/Fisheries Center of \\ Excellence, University of Arkansas at Pine Bluff, I200 North University Drive, MS 49/2, \\ Pine Bluff, Arkansas 71601 USA
}

Carole R. Engle

Aquaculture/Fisheries Center of Excellence, University of Arkansas at Pine Bluff. 1200 North University Drive, MS 4912, Pine Bluff. Arkansas 71601 USA

\begin{abstract}
Catfish farmers increasingly are producing fish larger than the traditional size of $0.45-0.57$ $\mathrm{kg} /$ fish in order to meet processing plant requirements for larger fish. Production of larger channel catfish Ictalurus punctatus in multiple-batch culture has been investigated in a few studies, but the impact of understocked fingerlings on growth of carry-over fish is unknown. The present study was conducted to quantify growth, feed conversion ratio, net daily yield, and net and total yield of stocker channel catfish grown in single-batch, one-season culture to mean individual weights of $0.60,0.72,0.91$, or $1.17 \mathrm{~kg} / \mathrm{fish}$. Channel catfish (mean weight $=0.26 \mathrm{~kg} / \mathrm{fish}$ ) were stocked into $12 \mathrm{0.1}$-ha ponds at $11,115 \mathrm{fish} / \mathrm{ha}$. Fish were fed a $32 \%$ crude protein floating extruded feed once daily to apparent satiation. When the average weight of the fish population reached the target weight, three randomly selected ponds were harvested. Fish growth was linear in all treatments. Growth rates were similar for fish grown to $0.60,0.72$, and $0.91 \mathrm{~kg} / \mathrm{fish}$, and significantly lower $(P<0.05)$ than for fish grown to 1.17 kg. Variation in individual fish weight increased linearly with increased duration of culture period. Feed conversion ratio averaged 1.9 and did not differ significantly among treatments. The percentage of the fish population at harvest that fell within the 0.57 to $2.04 \mathrm{~kg}$-size range preferred by processing plants increased from 56.6 to $98.5 \%$ as the mean weight at harvest increased from 0.60 to $1.17 \mathrm{~kg} / \mathrm{fish}$.
\end{abstract}

Channel catfish Ictalurus punctatus traditionally are harvested for processing when their individual weight ranges from $0.45-0.57 \mathrm{~kg}$. Increasingly, processing plants require farmers to provide fish with a mean weight of $0.57 \mathrm{~kg}$ or greater as processors respond to changes in market demand and strive to increase processing efficiency. Typically, channel catfish are reared to market size in a multiple-batch production system where the fish population is comprised of two or more cohorts of fish (Tucker and Robinson 1990; Terhune et al. 1997). Two production seasons are required for fingerling catfish to attain market size. While farmers have adapted production systems to comply with the new processing size requirements, there is little data in the scientific literature on the growth of channel catfish larger than $0.57 \mathrm{~kg}$.
Production of large catfish has been studied on a limited basis. Busch (1986) found that age- 2 channel catfish $(0.68 \mathrm{~kg}$ mean weight) could grow to $1.41 \mathrm{~kg}$ during one production season. However, the stocking rate used by Busch (1986) was only $25 \%$ of stocking rates used currently and fish growth samples were not made during the culture period. Production of large (0.9-1.0 kg mean weight) channel catfish was examined in a two-year study, but fish growth and population size structure at harvest were not evaluated ( $\mathrm{Li}$ et al. 2001). Thus, the present study was conducted to quantify growth, feed conversion ratio, net daily yield, and net and gross yield resulting from stocker channel catfish grown in singlebatch, one-season culture to mean individual weights of $0.60,0.72,0.91$, or $1.17 \mathrm{~kg}$. In addition, the percentage of fish weighing

$$
\text { e Copyright by the World Aquaculture Society } 3004
$$




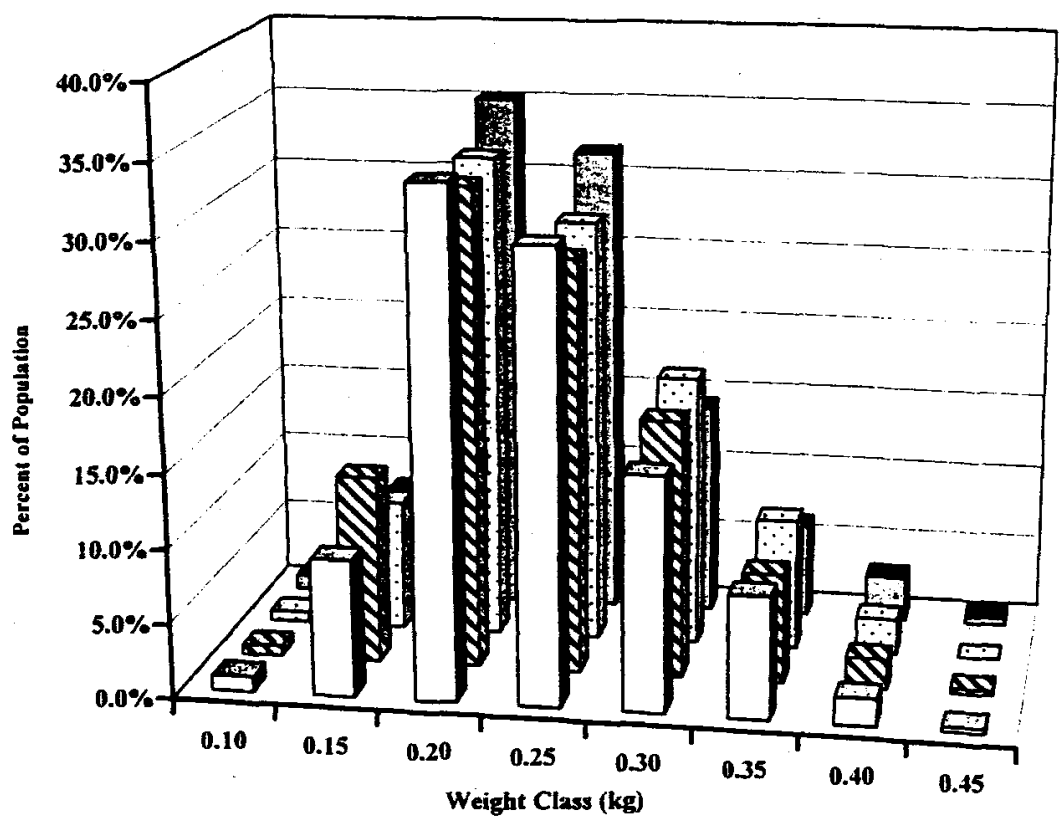

FIGURE 1. Frequency distribution by treatment of individual weight classes of channel catfish stocked into 0.1 ha earthen ponds at 11.115 fish/ha. The global mean individual weight $( \pm S D$ ) at stocking was $0.26 \pm 0.06$ kg/fish.

from 0.57 to $2.04 \mathrm{~kg} / \mathrm{fish}$ was determined for each treatment.

\section{Materials and Methods}

Twelve 0.1-ha earthen ponds located on the Aquaculture Research Station, University of Arkansas at Pine Bluff, were stocked with 11,115 stocker channel catfish/ha on 3 April 2001. At stocking, $200 \mathrm{fish} /$ pond were selected randomly and weighed individually to the nearest $0.005 \mathrm{~kg}$ (Fig. 1). Catfish averaged ( $\pm \mathrm{SD}) 0.26 \pm 0.06 \mathrm{~kg} / \mathrm{fish}$ at stocking. An additional 10 catfish were stocked into each pond on 4 April 2001 to compensate for stocking-related mortality.

Fish were fed a $32 \%$ crude protein extruded floating catfish feed once daily to apparent satiation, defined as the amount of feed the fish in each pond consumed in $\mathbf{3 0}$ min. The weight of feed fed to each pond was recorded daily. Fish were not fed during sampling, harvest, or disease outbreaks. Dissolved oxygen concentrations and temperatures were measured in ponds daily and recorded at about 0700 and $1600 \mathrm{~h}$. Each pond was equipped with a $0.37-\mathrm{kW}$ electric paddlewheel aerator and ponds were aerat.ed nightly to maintain dissolved oxygen concentrations greater than $3.5 \mathrm{mg} / \mathrm{L}$. Duration of nightly aeration increased as daily feed ration and pond water temperature increased. When necessary, ponds were aerated during the day to maintain the minimum dissolved oxygen concentration.

The fish population in each pond was sampled using a seine net $(1.27-\mathrm{cm}$ square mesh) at approximately $30-d$ intervals beginning $65 \mathrm{~d}$ after stocking. At each sample, 
TABLE 1. Mean ( \pm SEM) gross and net yields, survival, and feed conversion ratio (FCR) of stocker channel catfish grown in 0.1-ha earthen ponds (11,115 fish/ha) to mean individual harvest weights of $0.60,0.72,0.91$, or $1.17 \mathrm{~kg} / \mathrm{fish}$. Mean initial stocker weight was $0.26 \mathrm{~kg} / \mathrm{fish}$.

\begin{tabular}{|c|c|c|c|c|c|c|}
\hline \multirow[b]{2}{*}{ Treatment } & \multirow{2}{*}{$\begin{array}{l}\text { Final weight } \\
\text { (kg/fish) }\end{array}$} & \multirow{2}{*}{$\begin{array}{l}\text { Duration } \\
\text { (d) }\end{array}$} & \multicolumn{2}{|c|}{ Yield (kg/ha) } & \multirow{2}{*}{$\begin{array}{c}\text { Survival } \\
(\%)\end{array}$} & \multirow[b]{2}{*}{ FCR } \\
\hline & & & Gross & Net & & \\
\hline 1 & $0.60 \pm 0.009$ & 98 & $6,066 \pm 250.6$ & $3,062 \pm 258.7$ & $94.4 \pm 0.20$ & $2.0 \pm 0.15$ \\
\hline 2 & $0.72 \pm 0.014$ & 134 & $7,470 \pm 134.3$ & $4,468 \pm 131.5$ & $93.5 \pm 0.05$ & $1.9 \pm 0.02$ \\
\hline 3 & $0.91 \pm 0.016$ & 164 & $8,946 \pm 256.1$ & $5.919 \pm 250.3$ & $89.7 \pm 0.20$ & $2.0 \pm 0.05$ \\
\hline 4 & $1.17 \pm 0.021$ & 210 & $11,368 \pm 471.0$ & $8,355 \pm 464.3$ & $82.9 \pm 0.07$ & $1.8 \pm 0.04$ \\
\hline
\end{tabular}

$200 \mathrm{fish} /$ pond were selected at random, weighed individually (to the nearest 0.005 $\mathrm{kg}$ ), and returned to the pond. When the mean individual weight for all fish sampled reached $0.60 \mathrm{~kg}$, three randomly selected ponds were harvested by draining. Additional groups of three ponds were harvested when mean individual weight was 0.72 , 0.91 , or $1.17 \mathrm{~kg}(134,164$, or $210 \mathrm{~d}$ poststocking). The mean final weights of 0.60 , $0.72,0.91$, and $1.17 \mathrm{~kg} /$ fish are designated as Treatments $1,2,3$, and 4 , respectively. At harvest, all fish in each pond were counted and weighed en masse (to the nearest $0.5 \mathrm{~kg}$ ) and a random sample of 200 fish were weighed individually (to the nearest $0.005 \mathrm{~kg}$ ).

Catfish length at harvest was calculated for each treatment with the equation, $\mathrm{L}^{3}=$ W/0.00002877, where $L=$ length in inches and $\mathbf{W}=$ weight in pounds (Piper et al. 1982). The daily increment in length $(\mathrm{mm} /$ d) for each treatment was regressed against mean water temperature for that treatment.

During harvest on catfish farms, catfish are captured by seine and transferred into a grader sock to passively size-grade. Commonly used grader sock square mesh sizes are $4.13,4.45$, or $5.08 \mathrm{~cm}$, which retain fish of approximately $0.45,0.68$, and $0.79 \mathrm{~kg} /$ fish, respectively (Tucker and Robinson 1990). The mean size distribution of fish in each treatment at harvest was used to calculate the percentage of the population that would be retained by each of the above three sizes of grader net based on the cited cut-off weights.
Data were analyzed by ANOVA, ANCOVA, and regression analysis; percent data were arcsin transformed before analysis (Sokal and Rohlf 1995). Data analyses were performed using SAS version 8 software (SAS Institute Inc., Cary, North Carolina, USA). Slopes of growth curves for each treatment were compared using covariant analysis. Skewness and kurtosis were calculated for the distribution of individual fish weights in each pond at harvest using PROC UNIVARIATE, SAS version 8 software. Feed conversion ratio was calculated by dividing the total quantity of feed fed by the net yield. Differences were declared significant at alpha level 0.05 .

\section{Results and Discussion}

Gross catfish yield increased linearly with time from a mean of $6,066 \mathrm{~kg} / \mathrm{ha}$ after $98 \mathrm{~d}$ to a mean of $11,368 \mathrm{~kg} / \mathrm{ha}$ after $210 \mathrm{~d}$ (Table 1). Mean net yield of catfish ranged from 3,062-8,355 $\mathrm{kg} / \mathrm{ha}$, also increasing linearly with time (Table 1). Stocker catfish grew to $0.60 \mathrm{~kg} /$ fish after $98 \mathrm{~d}$ and to 1.17 $\mathrm{kg} /$ fish after $210 \mathrm{~d}$ (Table 1).

Catfish growth in all treatments was linear (Fig. 2). Fish grown to $1.17 \mathrm{~kg}$ /fish did not appear to grow following the day -190 (10 October 2001) growth sample, likely because a cold front lowered mean early morning pond water temperature to $16.8 \mathrm{C}$. Daily feed consumption in these ponds averaged $96 \mathrm{~kg} / \mathrm{ha}$ during the $10 \mathrm{~d}$ before the cold front arrived, but decreased to a mean of $34 \mathrm{~kg} / \mathrm{ha}$ for the final $18 \mathrm{~d}$ of culture. Growth rates did not differ significantly for 


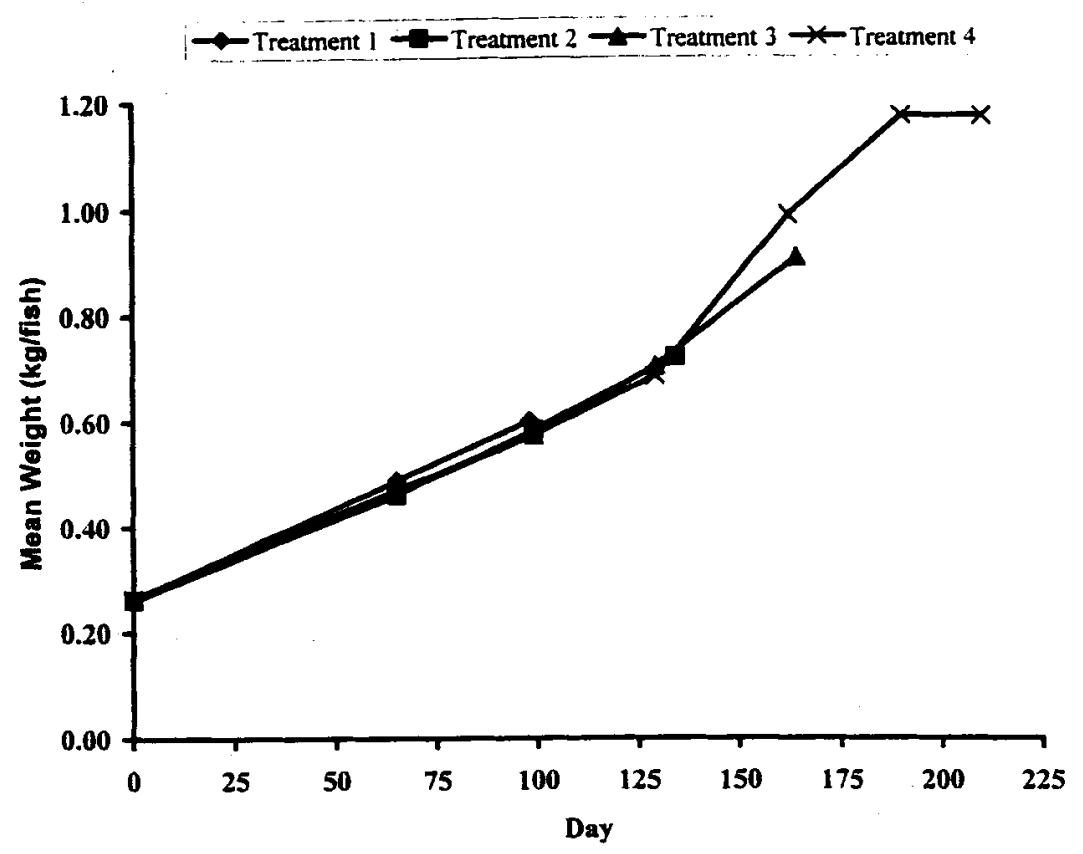

FIGURE 2. Growth curves for stocker catfish to mean final weights of $0.60 .0 .72,0.91$, or $1.17 \mathrm{~kg} / \mathrm{fish}$ (Treatments 1 to 4 respectively.). Catfish were stocked at 11.115 fish ha in 0.1 -ha earthen ponds and fed a 32\% protein floating extruded feed once daily to apparent satiation.

catfish grown to mean harvest weights of $0.60,0.72$, or $0.91 \mathrm{~kg} / \mathrm{fish}$, but were significantly less than the growth rate for catfish grown for $190 \mathrm{~d}$ to a $1.17 \mathrm{~kg} / \mathrm{fish}$ mean harvest weight. The same result was obtained when the analysis included growth data through day 210 (harvest) for fish grown to $1.17 \mathrm{~kg} /$ fish. However, growth rates did not differ significantly among treatments for fish growth through the first $164 \mathrm{~d}$ of culture. Thus, catfish growth rate increased once fish exceeded $0.91 \mathrm{~kg} / \mathrm{fish}$.

Fish survival ranged from $94.4 \%$ in Treatment 1 to $82.9 \%$ in Treatment 4 (Table 1 ), and decreased linearly with duration of culture $\left(R^{2}=0.639, P=0.0018\right)$. Differential survival may have affected densitydependent fish growth in Treatment 4, which could explain the faster growth observed. However, analysis of covariance showed that the mean individual fish weight at harvest was not affected significantly by survival $(P=0.56)$. Hopkins and Yakupitiyage (1991) reported a $7 \%$ positive bias on estimates of tilapia size by seine sample.
Seine sample bias may have affected the Treatment 4 growth curve as well as growth curves for the remaining treatments. However, the persistence of a difference when day-210 (harvest) data for Treatment 4 are included excludes this explanation. Thus, the significantly greater growth rate observed in Treatment 4 likely resulted from higher absolute growth of larger fish.

Mean pond water temperature was 21.9 $\mathrm{C}$ in April, 25.3 C in May, 28.2 C in June, $31.2 \mathrm{C}$ in July, 29.5 $\mathrm{C}$ in August, $26.0 \mathrm{C}$ in September, and 19.4 C in October. The maximum and minimum water temperatures recorded were 38.1 and $14.2 \mathrm{C}$, respectively. The mean daily increment in length was $1.03,0.96,1.00$, and $1.35 \mathrm{~mm} /$ $\mathrm{d}$ for catfish grown to $0.60,0.72,0.91$, and $1.17 \mathrm{~kg} / \mathrm{fish}$, respectively. Mean corresponding water temperatures were 25.6, $27.0,27.2$, and $26.4 \mathrm{C}$, respectively. In a tank study where water temperature was maintained at $24,26,28$, or $30 \mathrm{C}$, the optimal growth and feed conversion for channel catfish was from 28 to $30 \mathrm{C}$ (Andrews 

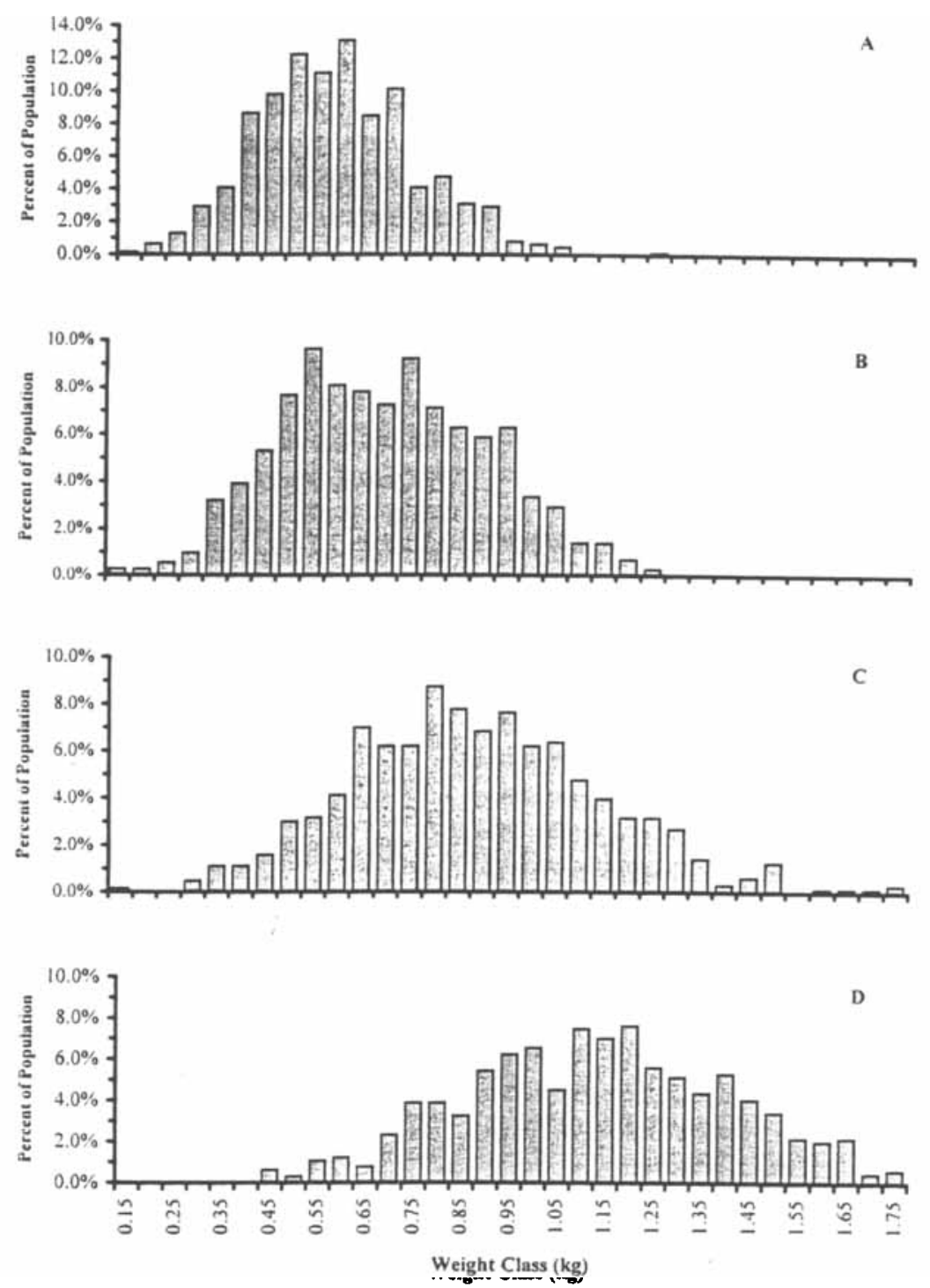

FIGLRE 3. Frequency distribution by treatment of individual channel catfish weight classes at harvest. Fish were stocked in 0.1 -ha earthen ponds at 11,115 fish/ha and grown to a mean final weight of $0.60 \mathrm{~kg} / \mathrm{fish}(\mathrm{A})$. $0.72 \mathrm{~kg} / \mathrm{fish}(B), 0.91 \mathrm{~kg} / \mathrm{fish}(C)$, or $1.17 \mathrm{~kg} / \mathrm{fish}(D)$.

et al. 1972). Soderberg (1992) used the data of Andrews et al. (1972) to develop linear growth models for channel catfish. Daily growth (calculated as $\mathrm{mm} / \mathrm{d}$ ) increased as temperature increased from 24 to $28 \mathrm{C}$, but at $30 \mathrm{C}$ was less than at $28 \mathrm{C}$ (Soderberg 1992). Regression equations were developed for the 24-30 C and 24-28 C ranges, with the best fit reported for the latter temperature range (Soderberg 1992). The mean daily increment in length in the present study was independent of mean water temperature, likely because of the narrow range of mean water temperatures. Because pond water temperatures varied throughout the present study, the mean daily length increments $(\mathrm{mm} / \mathrm{d})$ were lower compared to values reported by Soderberg (1992), where treatment water temperatures were constant.

Mean net daily catfish yield ranged from 
TABLE 2. Mean values of skewness and kurtosis for distribution of mean individual weight ( $k g / f i s h$ ) and the interquartile range for populations of stocker channel catfish grown to mean final weights of 0.60 . $0.72,0.91$, or $1.17 \mathrm{~kg} /$ fish (Treatments 1 to 4 , respectively). Means in columns followed by different letters are significantly different $(\mathrm{P}<0.05)$.

\begin{tabular}{ccrc}
\hline Treatment & $\begin{array}{c}\text { Skewness } \\
\left(g_{1}\right)\end{array}$ & $\begin{array}{c}\text { Kurtosis } \\
\left(g_{2}\right)\end{array}$ & $\begin{array}{c}\text { Interquartile } \\
\text { range (kg/fish) }\end{array}$ \\
\hline 1 & $0.336 \mathrm{a}$ & $0.066 \mathrm{a}$ & $0.48-0.70$ \\
2 & $0.170 \mathrm{a}$ & $-0.530 \mathrm{a}$ & $0.56-0.88$ \\
3 & $0.256 \mathrm{a}$ & $-0.001 \mathrm{a}$ & $0.72-1.08$ \\
4 & $0.168 \mathrm{a}$ & $-0.161 \mathrm{a}$ & $0.96-1.37$ \\
\hline
\end{tabular}

$31.2 \mathrm{~kg} / \mathrm{ha}$ in Treatment 1 to $39.8 \mathrm{~kg} / \mathrm{ha}$ in Treatment 4 , and increased linearly with increased duration of grow out $\left(R^{2}=0.57, P\right.$ $=0.005$ ). In a $155-\mathrm{d}$ pond study, net daily yield averaged $55 \mathrm{~kg} / \mathrm{ha}$ for catfish stocked at 17,300 fish/ha and fed a $32 \%$ crude protein diet to satiation (Robinson and $\mathrm{Li}$ 1999). Catfish stocked in earthen ponds at $18,530 / \mathrm{ha}$ and fed a $32 \%$ crude protein diet to satiation for $160 \mathrm{~d}$ had a mean net daily yield of $40 \mathrm{~kg} / \mathrm{ha}$ ( $\mathrm{Li}$ et al. 2000). Mean net daily yields observed in the present study were consistent with values reported from other catfish pond production trials. The pond carrying capacity in the present study had not been reached in any treatment because catfish biomass continued to increase with duration of culture period.

The mean feed conversion ratio (FCR) ranged from 1.8 to 2.0 and did not differ significantly among treatments (Table 1). The FCRs obtained in this study are similar to FCR values of 2.0 to 2.1 for channel catfish grown from $0.06 \mathrm{~kg} /$ fish to 0.94 to 1.01 $\mathrm{kg} /$ fish during two production seasons ( $\mathrm{Li}$ et al. 2001). Catfish grown from 0.03 to $0.59 \mathrm{~kg}$ in single-batch culture $(11,120 \mathrm{fish} /$ ha) during a single season had an FCR of 1.4 (Tucker et al. 1993). In another series of studies, FCR averaged 1.4 for channel catfish grown from $0.04 \mathrm{~kg}$ to $1.2 \mathrm{~kg}$ during two production seasons, 2.2 for catfish grown from 0.04 to $0.5 \mathrm{~kg}$ during a single season, and 2.6 when catfish were grown from 0.45 to $1.2 \mathrm{~kg}$ during a single season (Robinson and Robinette 1993). An FCR of 2.2 was reported for channel catfish grown from $0.68 \mathrm{~kg}$ to $1.41 \mathrm{~kg}$ during one production season (Busch 1986). Robinson and $\mathrm{Li}$ (1999) reported a mean FCR of 1.8 for catfish grown in single-batch culture from 0.37 to $0.89 \mathrm{~kg}$ during one growing season. Thus, FCR values observed in the present study are within the range of FCR values reported for pond production of similarly sized channel catfish.

The variation in individual weight of the catfish population at harvest increased linearly $\left(R^{2}=0.91, P=0.0001\right)$ as the mean individual weight at harvest increased. Mean frequency distributions of individual weights by treatment at harvest are shown in Fig. 3. Increased variability can affect measures of central tendency of the population. Skewness is a measure of the symmetry of the distribution and is equal to zero for a symmetrical distribution (Sokal and Rohlf 1995). Mean values of skewness $\left(g_{1}\right)$ for the harvest weight distribution among treatments ranged from 0.168 to 0.336 , indicating a distribution symmetrical

TABLE 3. Calculated mean percentage of the catfish population at harvest above or below a specific mean individual weight ( $k g / f i s h$ ) and within the $0.45-0.57 \mathrm{~kg} / f i s h$ size range, and the maximum fish size when stocker channel catfish were grown to mean final weights of $0.60,0.72,0.91$, or $1.17 \mathrm{~kg} / \mathrm{fish}$.

\begin{tabular}{ccccccccc}
\hline & $\begin{array}{c}\text { Final weight } \\
\text { Treatment }\end{array}$ & $\mathbf{k g} /$ fish $)$ & $<0.45 \mathrm{~kg}$ & $<0.57 \mathrm{~kg}$ & $0.45-0.57 \mathrm{~kg}$ & $>0.68 \mathrm{~kg}$ & $>0.79 \mathrm{~kg}$ & $\begin{array}{c}\text { Maximum } \\
\text { weight } \\
\text { (kg/fish) }\end{array}$ \\
\hline 1 & 0.60 & 17.7 & 43.4 & 31.3 & 29.3 & 12.9 & 1.12 \\
2 & 0.72 & 9.8 & 26.3 & 18.3 & 54.8 & 36.9 & 1.25 \\
3 & 0.91 & 3.0 & 8.1 & 5.3 & 81.1 & 67.3 & 1.70 \\
4 & 1.17 & 0.0 & 1.5 & 1.5 & 96.6 & 89.9 & 1.99 \\
\hline
\end{tabular}


about the mean (Table 2). No significant difference in skewness was detected among treatments. Kurtosis measures the amount of data in the tails as compared to the central part of the distribution, and a normal distribution has a kurtosis equal to zero (Sokal and Rohlf 1995). The distribution of individual catfish weights at harvest had mean kurtosis values $\left(g_{2}\right)$ among treatments that ranged from -0.530 to 0.066 , indicating slight platykurtosis to mesokurtosis (Table 2). Kurtosis values did not differ significantly among treatments. Thus, while individual weight at harvest became more variable as the population mean weight increased (or the duration of grow out increased), the shape of the frequency distribution did not change.

Of interest to catfish farmers is the percentage of the total population that is harvestable with a given mesh size of grader net and the percentage of harvested fish that are within a size range acceptable to the processor. Processors generally prefer fish in the 0.57 to $2.04 \mathrm{~kg}$ range, and producers may be subject to fines if their fish exceed the size limits by 10 to $20 \%$ at either or both ends of the range. In order to harvest fish of a desired minimum market size, farmers will seine the pond and confine the captured fish in a grader sock to allow submarketable fish to escape (Tucker and Robinson 1990). A grader sock constructed of $4.13-\mathrm{cm}$ square mesh is used to retain catfish with an approximate minimum weight of $0.45 \mathrm{~kg} / \mathrm{fish}$, while mesh sizes of 4.45 and $5.08 \mathrm{~cm}$ are used to retain fish with approximate minimum weights of 0.68 and $0.79 \mathrm{~kg} /$ fish, respectively (Tucker and Robinson 1990). The quantity of fish in the 0.45 to $0.57 \mathrm{~kg} / \mathrm{fish}$ range is important because processor limits on under-sized fish may be exceeded if fish are graded through a 4.13$\mathrm{cm}$ mesh sock. Note that grading efficiency is affected by a number of factors, including water temperature and dissolved oxygen concentration, and sock loading rate. Fortythree percent of the Treatment 1 fish population was smaller than $0.57 \mathrm{~kg} / \mathrm{fish}$, and
$31.3 \%$ of the population ranged from 0.45 to $0.57 \mathrm{~kg} /$ fish (Table 3). These values decreased to $1.5 \%$ and $1.5 \%$, respectively, in Treatment 4 (Table 3). Thus, harvesting catfish from single-batch culture when the population mean weight is $0.60 \mathrm{~kg} / \mathrm{fish}$ will not yield large quantities of fish of acceptable size to processors irrespective of grader sock mesh size. When the population mean weight increased to $0.72 \mathrm{~kg} / \mathrm{fish}$, $18.3 \%$ of the population was in the 0.45 to $0.57 \mathrm{~kg} / \mathrm{fish}$ range, and $54.8 \%$ of the population was larger than $0.68 \mathrm{~kg} /$ fish (Table $3)$. Thus, harvest of economically viable quantities of fish may be possible if the fish are graded through a $4.45-\mathrm{cm}$ square mesh grader sock. At a mean population weight of $0.91 \mathrm{~kg} / \mathrm{fish}$ and larger, a complete pond harvest is possible without having to grade fish and without exceeding processor size limits. No fish in any treatment exceeded the processor upper size limit (Table 3 ).

In summary, stocker channel catfish exhibited fast, linear growth from $0.26 \mathrm{~kg} / \mathrm{fish}$ to $1.17 \mathrm{~kg} / \mathrm{fish}$ in single-batch culture. However, the variability in mean individual fish weight increased with increased duration of grow out. The feed conversion ratio did not deteriorate for fish grown from a mean initial weight of $0.26 \mathrm{~kg} / \mathrm{fish}$ to mean final weights of 0.60 to $1.17 \mathrm{~kg} / \mathrm{fish}$. At harvest, less than $10 \%$ of the population was smaller than $0.57 \mathrm{~kg} / \mathrm{fish}$ when catfish were grown to mean weights of 0.91 or $1.17 \mathrm{~kg} /$ fish in single-batch culture.

\section{Acknowledgments}

The authors thank Arkansas Catfish Promotion Board for providing funding for this study. Carl Jeffers and Jeff Baxter are thanked for providing the stocker catfish.

\section{Literature Cited}

Andrews, J. W., L. H. Knight, and T. Murai. 1972. Temperature requirements for high density rearing of channel catfish from fingerling to market size. Progressive Fish Culturist 34:240-241.

Busch, R. L. 1986. Third year growth of channel catfish. Progressive Fish-Culturist 48:188-189.

Hopkins, K. and A. Yakupitiyage. 1991. Bias in 
seine sampling tilapia. Journal of the World Aquaculture Society 22:260-262.

Li, M. H., B. G. Bosworth, and E. H. Robinson. 2000. Effect of dietary protein concentration on growth and processing yield of channel catfish Ictalurus punctatus. Journal of the World Aquaculture Society 31:592-598.

Li, M. H., B. B. Manning, E. H. Robinson, and B. G. Bosworth. 2001. Effect of dietary protein concentration on growth and processing yield of channel catfish, Ictalurus punctatus, raised from advanced fingerlings to large marketable size. Journal of Applied Aquaculture 11:49-56.

Piper, R. G., I. B. McElwain, L. E. Orme, J. P. MeCraren, L. G. Fowler, and J. R. Leonard. 1982. Fish hatchery management. United States Department of the Interior. Fish and Wildlife Service, Washington, D.C., USA.

Robinson, E. H. and M. H. Li. 1999. Effects of dietary protein concentration and feeding rate on weight gain, feed efficiency, and body composition of pond-raised channel catfish Ictalurus punctatus. Journal of the Worid Aquaculture Society $30: 311-318$.
Robinson, E. H. and H. R. Robinette. 1993. Effects of dietary protein level and feeding regimen on growth and fattiness of channel catfish, Ictalurus punctatus. Journal of Applied Aquaculture 3:6789.

Soderberg, R. W. 1992. Linear growth models for intensive aquaculture. Progressive Fish Culturist 54:255-258.

Sokal, R. R. and F. J. Rohlf. 1995. Biometry: the principles and practice of statistics in biological research, third edition. W. H. Freeman and Company, New York, New York, USA.

Terhune, J. S., T. E. Schwedler, W. R. English, and J. A. Collier. 1997. Channel catfish production with combination and replacement stocking. Progressive Fish-Culturist 59:20-24.

Tucker, C. S. and E. H. Robinson. 1990. Channel catfish farming handbook. Van Nostrand Reinhoid, New York, New York, USA.

Tucker, C. S., J. A. Steeby, J. E. Waldrop, and A. B. Garrard. 1993. Production characteristics and economic performance of four channel cattish. $I c$ talurus punctatus, pond stocking density-cropping system combinations. Journal of Applied Aquaculture 3:333-351. 